\title{
Outside but Along-Side: Stumbling with Social Movements as Academic Activists
}

\author{
ALEX KHASNABISH \\ Mount Saint Vincent University, Canada \\ MAX HAIVEN \\ Nova Scotia College of Art and Design, Canada
}

\begin{abstract}
In this article, we critically reflect on the production and measurement of 'success' and 'failure' both in social movements and social movement research. We do so by focusing on the Radical Imagination Project, an experiment in politically engaged, ethnographically grounded social movement research we have sustained in Halifax, Nova Scotia since 2010. We discuss our methodological strategy of 'convocation,' distinguishing it from other social movement research approaches, and reflect on the difficulties inherent in practicing these methods within the austere realities and pressures of the neoliberal university. We explore the ways in which the particular complexities of the fraught field and habitus of the would-be academic-activist might be critically assessed and best mobilized to assist in the reproduction of movements, without also unduly reproducing the neoliberal university or its architectures of privilege and power.
\end{abstract}

KEYWORDS social movements; social movement research; solidarity research; radical imagination; social change; social reproduction; neoliberalism; academic activism

In this article, we reflect on the successes and failures (and, indeed, the discursive production of 'success' and 'failure') in social movements and social movement research. In particular, we focus on the Radical Imagination Project, an experiment in politically engaged, ethnographically grounded social movement research we have sustained in Halifax, Nova Scotia since 2010. The project, which combines intensive interviews, community focus groups, educational events, and participant observation, has been guided by the principle that we, as researchers, want to do more than merely observe social movements at work. We want to instead explicitly and intentionally create new atmospheres and processes to 'convoke' the radical imagination. 
Thus, we have developed a practice of working outside but alongside the small but energetic and diverse activist movements in the city.

In response to the question of the potentials, pleasures, and perils of 'academic activism', we wish to explore the possibilities for leveraging the complex and fraught privileges and opportunities provided to academics in order to create resources for movements that they might not otherwise possess or create. We distinguish our methodological strategy of 'convocation' from both 'invocation' (where researchers observe and report on movements) and 'avocation' (where researchers are called away by movements to submit their skills to movement-led projects). We reflect on the difficulties inherent in practicing these methods within the austere realities and pressures of the neoliberal university.

Theoretically, we approach the problem through materialist feminist conceptions of social reproduction and the potentiality of the commons, asking how both movements and researchers 'reproduce' themselves (or fail to do so). We are interested in the ways in which the particular complexities of the fraught field and habitus of the would-be academic-activist might be critically assessed and best mobilized to assist in the reproduction of movements, without also unduly reproducing the neoliberal university or its architectures of privilege and power. This is all the more important in an age of political-economic crisis, which has included the repression of social movements (Wood, 2014) and in which fragmentation, diffusion, segmentation, and diversity are the norm in movement cultures.

\section{Three Models of Reproduction}

This essay builds on a three-part theory of reproduction which integrates Marxist, cultural studies, and materialist feminist approaches to offer a framework for understanding how individuals, institutions, and systems interact amidst complex crises.

From a Marxist perspective, reproduction refers the questions of the reproduction of capital as sketched initially by Karl Marx (1981) and developed more fully by theorists such as Rosa Luxemburg (2003) and Louis Althusser (2014). Marx, famously, focused his analysis of capitalism on the production of wealth and the extraction of surplus value, but only elliptically and in fits and starts described the ways in which the crisis-prone system was reproduced as a whole. For Marx and subsequent thinkers, capitalism is driven, ultimately, by contradictions which, if unmet, lead to systemic crises (see Harvey, 2006). For instance, industrial capitalism requires the aggregation of proletarians in factories, but affords them the opportunity to organize and rebel. Likewise, competition drives individual capitalists to constrain wages and mechanize production to create commodities more cheaply, but this leads to depressed wages and unemployment and, hence, lowers demand for commodities and heightens the possibility of revolt. 
Capital develops an array of techniques to temporarily 'fix' these contradictions, usually by 'externalizing' them onto vulnerable and marginalized populations (De Angelis, 2007; Harvey, 2006). Such 'fixes' include: the expansion of markets through colonialism; the use of fascism and other repressive regimes to take more authoritarian control over the economy and workers' lives; the destruction of social surplus through military expenditure and war; the use of advertising and marketing to expand the field of desires and demands; and the growth of the prison-industrial and educational-industrial complexes as a means to warehouse surplus workers without endangering the inherent logic of the system (Davis, 2005).

The second valence of reproduction draws on the work of post-war cultural studies scholars and refers to the ways in which class and other power relations are reproduced between individuals, institutions, and systems (Bourdieu, 1993; Hall, 1986, 1997; Hoggart, 1998). For instance, ruling class cultural institutions, from private schools to the opera, from dinner clubs to professional associations, all provide a venue in which class relations and sensibilities can be reified, reinscribed, and reproduced through social interactions. Likewise, popular cultural spaces and practices can offer the means to awaken dwindling class consciousness among the working class and offer the potential to subvert and transform the status quo and the ruling class interests it embodies. Several generations of feminist and queer scholars (e.g., Butler, 2006; Eisenstein, 2004; Haraway, 1991; hooks, 2000; Mohanty, 2003) have investigated the ways in which gender is socially constructed and reproduced through social institutions, cultural norms, popular media, social interaction, and structures of power. Anti-racist scholars have mapped how the meaning of skin colour, accented speech, (presumed) ancestral origins, and socioeconomic status all fold into the reproduction of race (e.g., Fanon, 1982; Gilroy, 1993; Hall, 1993; Mills, 1997).

The final valence of reproduction draws on the materialist feminist tradition of Maria Mies (1986), Vandana Shiva (1988), Silvia Federici (2003, 2012), and Mariarosa Dalla Costa and Selma James (1975), among others, who argue that attention to reproductive labour is central to an understanding of both capitalist and patriarchal power dynamics. While Marx based his analysis of capital and struggle on the productive apparatus of society - the means of production - these authors note that the largely unwaged, feminized work of reproducing social life, which ranges from bearing and raising children to maintaining the family and community, is the actual bedrock of material social relations. Without the production of new workers, and the reproduction of workers' bodies and souls within the unpaid workshop of the family, there could be no 'production'. Today, with the rise of the so-called service sector as a key economic realm, we have seen this reproductive labour move into the formal waged economy and become more directly subjected to capitalist labour discipline. Moreover, the sector remains largely 'feminized': women are overrepresented and, due to persistent and evolving patriarchal 
conditions, work remains highly exploitative, precarious, and poorly paid (see Federici, 2012).

Recognizing capitalism's parasitical appropriation of the work of social reproduction allows us to see it for what it is: secondarily, a system of production; primarily, a society-spanning system in which the reproduction of social life itself is always and everywhere at stake. This recognition helps us overcome the tenacious tendency to posit an artificial break between a 'real' economic base and a contingent cultural or institutional 'superstructure'. This insight has been central to other radical theorists and practitioners, particularly those belonging to, or influenced by, the Italian Autonomia movement and its legacies. These have frequently focussed on the biopolitical nature of capitalism, the reorientation of capitalism away from an exclusive focus on the exploitation of labour and the production of commodities and toward the production or harnessing of social life and subjectivity (Caffentzis, 2013; Cleaver, 2000; Dyer-Witheford, 1999; Federici, 2012; Hardt \& Negri, 2000; Holloway, 2002, 2010).

Further, we can identify that capitalism functions only by conscripting and being conscripted to patriarchy, white-supremacy, colonialism, and other systems of power in order to reorient the reproduction of social life toward its own endless, limitless reproduction. As John Holloway (2010) so perceptively notes, the pre-condition for capitalism is the enclosure of our life-affirming, useful, concrete doing in the form of exchangeable, quantifiable, alienated, and abstracted labour. This means that we are, ultimately, the creators of the very social world that exploits us and reduces us to objects. In this context, as Marxist-feminists such as Federici (2003) and Mies (1986) have so incisively argued, primitive accumulation is not merely a historical phase of capitalist development. Rather, it refers to the constant drive of capital to colonize, marketize, and commodify the lifeworld and the sphere of social relationships. Capitalism is defined by struggle: on the one hand, individuals and communities constantly seek to develop resistant forms of autonomy, solidarity, and value within, against, and beyond capitalism; on the other, capital is constantly seeking to enclose, co-opt, and harness these spaces and processes so as to endlessly reproduce itself. Thus, capitalism names a struggle over the fabric of life itself and, as Holloway (2010) asserts, in this sense we are the crisis of capitalism both as we reproduce it as a system and as we struggle to reclaim our doing from it.

\section{The Crisis of Academic Reproduction}

As we have elaborated elsewhere (Haiven \& Khasnabish, 2014), we understand all crises to be, at some level, crises of capitalist reproduction, whether it is the global ecological crisis; the ongoing financial crisis; the crisis of the nation-state, which has given rise to all manner of demonic reactions (fundamentalism, ethnic nationalism, imperialism); or the crises of 
debt, anxiety, or alienation at the level of everyday life. All such crises result from the tension and friction between forces and movements at all three aforementioned levels of capitalist reproduction. Such an approach can offer us important insights into the contradictions within capitalism and, therefore, the sites and opportunities for leveraging social transformation. We see the university as one such site and the crises germane to the neoliberal academy as not merely a baleful curse, but an important set of structural transformations that can inform strategic interventions.

Other contributions to these special journal issues speak voluminously to the crisis of academe, whether it is the crisis of the liberal university's core mission (scholarly independence and values sacrificed on the altar of austerity), the crisis of academic labour (the rendering precarious of teaching and research staffing), the crisis of corporatization (industry partnerships, advertising), or the pedagogical crisis (the liquidation of critical thinking and radical thought in favour of streamlined curricula aimed at credentialization). For our part, we simply wish to map these overlapping crises onto the threefold theory of reproduction elaborated above. They each stem from conflicts between, on the one hand, the university's role as an institution built and maintained to reproduce capitalist economic and social relations and, on the other hand, the university as a site of struggle over the way social life will be reproduced for its inhabitants and for society at large (Edu-factory Collective, 2009; Haworth, 2012).

Those of us who survive, fitfully and precariously, within the university have become virtuosic at locating and cultivating spaces of abundance within and between its crisis tectonics. Because of this, we should not default to shamefaced hand-wringing over the relative luxury and privilege enjoyed by academic researchers when they interact with social movements and other actors. While no doubt partially true (though only for those of us fortunate enough to have tenure-track positions), we should also recognize our special competencies and opportunities as survivors within a hostile ecosystem, a virtuosity of survival that can inform the sorts of research we do, not primarily in order to generate data, but to catalyze radical social change.

In suggesting this we are not simply reifying the prowess of the academic as the consummate example of the neoliberal subject, deftly navigating and leveraging precarity toward the actualization of their own value. Following Moten and Harney (2013), we affirm that all knowledge is produced collectively and collaboratively, and that the university, in its hegemonic role, is an engine of theft whereby that common knowledge is enclosed, sorted, and revalued in the interests of the reproduction of capital and capitalism, with sometimes the side-effect of reproducing the academic as an elite worker-subject, with all the material and immaterial privileges that accrue. We are suggesting that academics need to pay careful attention to, and cultivate the particular latitudes of, freedom and potential they possess and put them to work in the interests of other forms of reproduction that strive toward the revolutionary transformation of social life and institutions. We are 
calling for a thorough examination of the differential, problematic, unequal, and highly contingent forms of virtuosity we have necessarily developed, not as a result of research or professionalization, but by virtue of survival within the increasingly hostile and austere academic workplace. This is a workplace that has, according to the Edu-Factory Collective (2009) and Andrew Ross (2009), come to prefigure and model new capitalist techniques and circuits for the extraction of value and intellectual and affective labour through the harnessing of subjectivity, the leveraging of precarity, and the flexible distribution of institutional risks and rewards. Our value to movements cannot be based only on our ability to redirect toward them the material and intellectual privileges of the university; instead, it must be based on a recognition of the particular forms of subjugation, subjectivity, and potential we encounter as academic subjects and the lateral, negotiated, difficult solidarity we can form with others encountering the same or other forms of subjugation.

\section{The Crisis of Movement Reproduction}

One of the most important insights offered by social movement scholarship, and one well-known by anyone who has spent any time working collectively with others in a struggle for social change, is that movements are not merely vehicles for contentious politics but laboratories for experiments in living and being in ways other than we are now (Day, 2005; Dixon, 2014; J. Juris, 2008; Maeckelbergh, 2009; Polletta, 2002; Sitrin, 2012; Sitrin \& Azzellini, 2014; Walia, 2013). Commonly referred to as prefigurative politics, at their most intentional and elaborate, such experiments seek explicitly to model the world movement participants want. In a more anarchistic vernacular, we might say that in this political vein the means of struggle must be commensurate with the desired ends.

From this perspective, we can understand movement cultures and politics as intertwined around the question of reproduction. The way movements reproduce themselves - that is, how they, in a day-to-day and organizational fashion, sustain themselves and their participants - has dramatic consequences for the kind of social reality they prefigure. Many movement participant-observers have noted that in the context of an increasingly austere and militarized state, the prospects for a politics that seeks to exert pressure on decision-makers through the spectacle of protest seem increasingly dim (Day, 2005; Dixon, 2014; Holloway, 2002; Sitrin \& Azzellini, 2014). This suggests that both movement participants and those researchers who seek to work with them ought to think differently about movements themselves. More than extra-institutional vehicles for contentious politics, movements are also the spaces for alternative forms of, and experiments in, social reproduction. For better or worse, they are spaces where people find and reproduce community. Movements are not only places where friendships and 
other relationships blossom, they are also undergirded by networks of sociality, care, and shared purpose. The activists we interviewed as part of our research on the radical imagination (discussed in greater detail below) often shared houses or practiced other forms of collective or communal living, they provided emotional and sometimes professional support for one another, and they often formed and based their activism on the strength and creativity of these social bonds. Movements thus become spaces where activists reproduce their bodies, their minds, and their souls.

How do we do research with social movements at a moment marked by a profound crisis of their reproduction? It is always a mistake to measure social movements' successes and failures only by the achievement of their stated objectives (e.g., particular policy changes, electoral victories, or fruitful campaigns) because it ignores the ways in which they create and sustain platforms for counter-hegemonic forms of social relationality and reproduction. In periods of social movement downturn, the costs of such narrow focus are magnified and lead to overly cynical and pessimistic assessments of the potential for social change. In such times, how might those of us who enjoy the conflicted, double-edged, and perhaps inherently unjust privileges of the (securely employed, funded) academic best put our powers to work not on, not for, but with social movements?

With these questions in mind we undertook a study of what we called the 'radical imagination'. We wanted to know what it was that animated the spirit of refusal, revolt, and reinvention that allowed social movements to sustain themselves even in the darkest of times. We wanted to understand how those who have a radical vision for changing the world in unlikely ways sustain and spread hope, courage, and conviction amidst what might appear, to an outside observer, like failure.

So what do we mean by the 'radical imagination'? The hegemonic notion of imagination comprehends it as an almost transcendental feature of the individual human brain. For us (see Haiven \& Khasnabish, 2011) it is, rather, a collective practice. The radical imagination is not something individuals possess; instead, it emerges from sparks between people as they work together to confront the inequalities and injustices of the dominant social order. In this sense, 'radical' does not refer to any particular political orientation but, rather, following the word's etymology, denotes an ability to trace social problems to their systemic roots. Following the work of Cornelius Castoriadis (1997), we understand the imagination as constantly at work in social life - indeed, the imagination is the magma-like substance out of which social institutions of all sorts are formed, from schools to prisons, the conventions of heteronormative love and marriage, to the stock market. In addition to physical and legal infrastructure, all social institutions are held in place and gain force through the shaping of social imaginaries (see also Appadurai, 1996; Taylor, 2004). The radical imagination, then, is generated in the tension between social actors and the 'imaginary' institutions and systems that surround them and to which they are conscripted. 
As such, studying the radical imagination requires unconventional tools. It cannot be observed and measured in a static form; it must be stimulated and experienced in struggle, debate, and contestation. Further, for those who wish to study in solidarity with movements (rather than perform research on movements), the objective cannot be mere observation but transformation. We sought to design a research agenda that took the crisis of social reproduction seriously, and that allowed us to better understand the ways in which movements both contest the disastrous reproduction of neoliberal capitalism and also provide spheres for experimenting with other modes and formations of care, sociality, and social reproduction.

Elsewhere, we (Khasnabish \& Haiven, 2012) have identified three key categories of research strategies that are explicitly 'in solidarity' with social movements: invocation, avocation, and convocation. Invocation could be said to represent the dominant voice of social movement studies in the academy. In this approach researchers make use of their academic status and standing both to legitimate and examine movements as vehicles for contentious politics. This stance has yielded important insights in terms of the dynamics of social movement activity and has also helped lend legitimacy in the eyes of some sceptics to non-institutional forms of political activity. Invocation also maintains the division between movements and those who study them and, in so doing, primarily produces knowledge about movements for a specialist academic audience. The second strategy is that of avocation: a calling away from. This posture describes researchers who, in a variety of ways, renounce the unjust autonomy and privilege of their academic status and seek to go to work within movements, putting their skills and whatever resources they may possess at the disposal of the movement itself. Forms of feminist action research and participatory action research often follow this path and have contributed vitally both to movements and community-based struggles, as well as to grounded knowledge about social change struggles from within. But avocation can only be a successful strategy when there are fully formed movements and organizations prepared to host and make use of engaged researchers.

What about when movements are in states of fragmentation or reconsolidation? This leads us to our third strategy of convocation: to call or summon something into being collectively. In this strategy, researchers seek to work dialogically with movements while retaining and seeking to make productive use of the unjust, unearned, but potentially fruitful autonomy and resources that accompany academic-based research. What kinds of possibilities open up to all of those who participate in a research process when the end goal is not the generation of units of academic knowledge to be converted into capital, but when the process itself becomes the goal; a way of making time and space for an open-ended grassroots inquiry guided by the collective? In this way, research becomes a way not merely of documenting or cataloguing movements, or any other social phenomenon for that matter, but of rigorously exploring the terrain of the possible. Thus, in the fall of 
2010, we initiated an ethnographically grounded, politically engaged social movement research project with self-identified radical social justice activists in Halifax, Nova Scotia. With a research team composed of the two of us as the project's co-directors and two research assistants recruited from the local social justice community, this project was configured as an experiment in research with rather than for or about social movements, with research as a catalyst for 'convoking' - collectively calling into being - the radical imagination. The project was funded initially by a two-year Standard Research Grant from the Social Sciences and Humanities Research Council of Canada (SSHRC) and thereafter through collaboration with a variety of academic programs and social justice organizations, as well as by grant money provided by Mount Saint Vincent University.

From Fall 2010 until the conclusion of our active research phase two years later, our research team interviewed more than 30 self-identified 'radical' social justice activists in Halifax. In semi-structured, open-ended, and indepth one-on-one interviews, we asked our participants about their political biographies, assessments of the status quo and the potential for social change, the best pathways for social change, experiences within social justice organizations, what it would mean to 'win', and what the future looked like. Drawing out emergent themes from our interviews, in the second year of the project we hosted a series of three 'dialogue' sessions in a public, accessible venue in Halifax, which was open and free to the public and to which our participants were invited. The three sessions were framed around issues and themes that had stood out to the research team in the interview stage: fighting back collectively in the age of austerity; the relationship between struggles against capitalism and struggles against oppressions; and the form and strategy of organizing today. The latter is essentially a question about more autonomous, grassroots, and horizontal forms of organizing versus more hierarchical, centralized, and disciplined ones like traditional Leftist parties. While this concluded the active research phase of the project, we later began to curate an ongoing speakers series through which we have brought researchers and activists from outside of Halifax's radical milieu to the city to give academic and public talks about their work and its relationship to struggles for radical social change in order to continue to stimulate dialogue about a variety of issues bearing upon social justice today.

In addition to publishing in academic venues about our work, we have disseminated our research in a variety of ways including: our project website (see http://radicalimagination.org); numerous presentations in public, activist, and academic contexts; shorter and more accessible pieces written for wider audiences and published on-line; media appearances, especially those in community and social justice venues; a two-day 'festival' of the radical imagination featuring eight local and visiting radical scholar-activists; and an audio documentary about the project featuring the voices of many of our participants that is, at the time of this writing, in the very final stages of production.

Studies in Social Justice, Volume 9, Issue 1, 18-33, 2015 
Like other engaged researchers, both within and outside of the academy, our research-based engagement with social movements and the diverse individuals and collectives who constitute them draws from a methodological toolbox that prioritizes grounded experiences and the lived reality of social life and struggles for social change (Conway, 2004; Dixon, 2014; Frampton, Kinsmen, Thompson, \& Tillezek, 2006; J. Juris, 2008; J. S. Juris \& Khasnabish, 2013; Khasnabish, 2008; Maeckelbergh, 2009; Sitrin, 2012; Sitrin \& Azzellini, 2014; Wood, 2012). Open-ended interviews, focus groups, public forums, and participant observation in the social justice milieu in Halifax made up the broadly ethnographic bedrock of our research. By ethnography we mean not only a research methodology including participant observation and in-depth interviews, but also a mode of writing and analysis that seeks to convey the subjective experience of being 'in the field'. Politically engaged, ethnographically grounded research with social movements also must adopt a somewhat different posture than ethnographic methodologies situated inside more conventional, objectivist paradigms. When the aim of research is not the generation of 'better data', but rather the facilitation of a dialogic process of grassroots, critical, and collective inquiry, its approach and outcomes become less descriptive and more catalytic.

As academically positioned researchers working in a spirit of solidarity with those struggling for social justice and change in the radical milieu in Halifax, we came increasingly to see our role less as scribes for, and interpreters of, movement activity and more as curators of critical, dialogic processes and encounters. In adopting this orientation to our research, we do so aware of and inspired by the ethnographically informed work of other politically committed scholar activists (see e.g., Conway, 2004; Frampton, Kinsmen, Thompson, \& Tilleczek, 2006; J. Juris, 2008; J. S. Juris \& Khasnabish, 2013; Khasnabish, 2008; Kinsman \& Gentile, 2010; Maeckelbergh, 2009; Sitrin, 2012). We are also very much aware that our own approach to scholarly activism (or activist scholarship) is only one point in a much wider constellation of attempts, both within and outside of the university, to carry out rigorous, critical inquiry with those engaged in struggles for radical social change and social justice (e.g., Colectivo Situaciones, 2011; Dixon, 2014; Frampton, Kinsmen, Thompson, \& Tilleczek, 2006; Harney \& Moten, 2013; Shukaitis, Graeber, \& Biddle, 2007; Sitrin \& Azzellini, 2014).

It is worth noting here that our research methodology and approaches to knowledge production have remained in the hands of the research team and, most specifically, in our hands as project co-directors. Unlike other approaches to community-engaged research we have not submitted the project as a whole to the control of the activist milieu in Halifax, though we would argue that when we began the project in 2010 the fragmentation and cleavages that marked the radical milieu in Halifax would have made this fraught, if not impossible. While other engaged researchers have gone to work with and within social movements in ways that have put the research 
process and its outcomes much more directly in the hands of their constituencies of concern than our own approach, we felt strongly about the value of our orientation and the need for the maintenance of a certain distance between the project and the community it sought to engage. Moreover, although we have not strayed far from fairly conventional models in terms of our written work emerging from the project, the diversity of our public educational initiatives (website, audio documentary, film and speakers series, the Festival of the Radical Imagination and other popular events) have been much more collaborative, democratic, and accessible in form, organization, and content.

Essentially, our goal was to craft a research methodology that understands the radical imagination as emerging within and between social movements as they engage with the three-fold crisis of capitalist reproduction at the level of political economy, at the level of society and subjectivity, and at the level of community and care. Movements, we found, imagine, develop, demand, and fight for both alternative models of social life (ways of living otherwise) and alternative orders of social reproduction (the way we organize the reproduction of social life itself) within, against, and beyond the capitalist order. At the same time, movements also operate as micro-communities: zones of alternative social reproduction that allow participants to form new social bonds based on their principles and aspirations. Yet, crucially, we found that these two goals - levelling a militant critique of social reproduction and modelling an alternative - were never quite in alignment. There was always tension and friction, conflict and experimentation occurring within and between movements and movement actors as they struggled through resisting the predations of the dominant order, advancing alternatives to it, and maintaining themselves as communities of care capable of nurturing and prefiguring ways of living otherwise. Through our research we found that these differences, tensions, and contradictions usually remained tacit, unspoken, and unacknowledged.

Our convocatory approach, then, was an attempt to leverage the unique (but also unfair and problematic) privileges and opportunities held by (tenuretrack) academics to create spaces and times for social movements to more explicitly and efficaciously address these contradictions. In this sense, we were influenced by the work of Fraco 'Bifo' Berardi (2009) when he suggests that in an age of neoliberal capitalist acceleration, when nearly all spheres of life, subjectivity, and sociality are 'enclosed' by the market and when social movements in many countries seem defeated, activism must comprehend itself on some level as a form of radical collective therapy. Translated into our terms, this would be a therapy to help individuals and movements understand and heal from being caught between the multiple contradictions of capitalist reproduction, as well as the contradictions germane to social movements as they seek to contest that order of reproduction and invent and practice new models of it. 


\section{Between Success and Failure}

Over the course of our active research phase, from 2010 to 2012, our research team noticed three distinct patterns emerge out of our one-on-one interviews with activists. The first was that some of the richest, most reflexive, and nuanced insights collaborators offered were in response to our interview question asking them to narrate their personal political biographies. Here, ideological beliefs and orientations corresponded to changes in individuals' life circumstances and relationships, further convincing us of the intertwined nature of the radical imagination and the conditions of social reproduction. The second was the almost uniformly bleak and dystopian way most activists spoke of their visions of the future, usually with explicit reference to the catastrophic consequences of anthropogenic climate change and the rise of totalitarian governments.

The third pattern that emerged from our interviews was that, when asked to describe what it would look like to 'win' (a question we borrowed from the Turbulence Collective, 2013), almost all our collaborators responded, after an uncomfortable pause, with brief, taciturn, and sometimes meekly apologetic or wryly sardonic answers. These answers were either extremely broad and abstract negations of the present order (e.g., "the end of capitalism") or highly particular (e.g., the passage of an all-too-often modest legislative reform). These responses confused us, expecting as we did that the tireless activism we were witnessing must be motivated by broad, rich, bold, and comprehensive visions of other possible worlds of social justice. We came to take a keen interest in the pregnant, uncomfortable pause that frequently preceded the answer. We named this significant gap 'the hiatus' (Haiven \& Khasnabish 2013) and came to see it as symptomatic of the double bind we have outlined above: on the one hand, movements must contest and confront the crisis of capitalist reproduction and, on the other, function as alternative models of social reproduction. The hiatus stems from a debilitating sense of inertia and failure in the face of the meagre or nonexistent pace of systemic change, often producing either activist burnout and movement dissolution or causing movements to turn inward and devolve into subcultures of solace in a heartbreaking world.

Compounding this is the fact that, in Halifax and many other small- to medium-sized urban centres, much important social justice work often gets done by a fairly small number of engaged people. In environments characterized by seemingly endless attacks on existing rights, much social justice activism becomes a defensive battle. With resources, time, and energy stretched thin, activists often face burn-out and its attendant negative consequences for physical, mental, and emotional health. All too often, activist spaces are sites of frenzied activity, self-exploitation, and sometimes toxic patterns of behaviour directed against self and others. The recognition of this has led to a protracted and important discussion about self- and community-care and how that might be considered within the larger 
framework of organizing. Such sensations and frustrations were all too familiar to us as academics bound up in and with an institution which, torqued by the force of neoliberal commodification, produces chronic fruitless overwork and destructive interpersonal and institutional drama.

These insights taught us a great deal about the realities of movement success and failure. As with individuals, movements do not spend their existence soaring in the airy heights of victory or mired in the depths of defeat. Indeed, the quotidian experience of social reproduction - of caring for ourselves and others and so renewing our capacity to labour - is the most common state for individual and collective entities in the world. As we have noted, in a very real sense this means that movements, as well as the individuals who make them up, dwell most commonly in the hiatus between success and failure. The significance of this recognition is that rather than focusing only or primarily on the most spectacular moments of movement activity, it is worth thinking about the tremendous amount of movementrelated work that goes on outside of these moments of high drama and how it relates to the nature and direction of the movement in question.

Hence, we discovered that our project was not primarily aimed at enabling movements to succeed, and indeed that our measurements and notions of success and failure were often misleading. If we attempt to ascertain the value and success of social movements purely by their ability to achieve concrete social changes, we miss a great deal about how they actually work. We miss the way they offer (intentionally or unintentionally) alternate forms of social reproduction. We also miss the role they often play as way-stations in the biography of individuals or the genealogy of ideas; the way movements, in spite of their objective victories or defeats, act as watersheds of the imagination, collecting, recycling, and redistributing ideas, techniques, visions, and people. We discovered that the role of our project was to hold space open for slower, more intentional critical conversations, to probe and question the often unspoken or unacknowledged tensions and possibilities within and between movements and within and between movement actors.

As a consequence of this, we were forced to re-examine our own notions of success and failure as academic-activists. We were not conventionally successful at collecting formally reliable data. Nor were we successful at stimulating some sort of revolutionary epiphany or energizing transformation in the movements we worked with. Yet we also did not fail. We experimented with a process which began with a critical and self-reflexive assessment of our own subject positions and virtuosity as subjects existing within, against, and beyond the neoliberal, crisis-wracked academy. Based on this, we devised and experimented with an investigation of the radical imagination based on meeting movements not as monolithic political actors but fragmented, fractured, and contradictory entities, made up of fragmented, fractured, and contradictory actors. For us, 'working alongside' movements means devising research that convokes the fabric of social contestation and 
the radical imagination. To do so, we need to complicate our notions of what success and failure might mean, both for movements and for research itself.

We are wagering this strategy of convocation on the belief that activistacademics working with social movements can envision themselves as more than either trusted insiders or privileged outsiders, but can instead imagine forms of solidarity research occurring along-side the movements they work with. Such an approach depends on an honest and forthright assessment of the opportunities and dangers the academic brings to table. But it also depends on a consideration of how the academic habitus produces us (and exploits us) as subjects and compels us to cultivate a virtuosity of resilience and persistence within an increasingly austere and hostile environment. All too typically this virtuosity is applied to the reproduction of the neoliberal university, which, evolving as a key institution within the high-pressure environment of the three-fold crisis of capitalist reproduction, adapts a system of rewards and punishments to elicit from us the virtuosic production of academic capital in the form of publications, service, teaching, and credentialization. Of course, in spite of the university's mythology, it is far from a meritocracy and the rewards and punishments, as well as the opportunities for resistance, are unevenly distributed along axes of race, class, gender, citizenship status, ethnicity, employment status, and other vectors of oppression. Yet we are keen to experiment with how academic virtuosity might be redirected, reappropriated, and repurposed in the interests of working with movements that are contending with the same tri-fold crisis of reproduction that gave rise to that virtuosity in the first place.

Here we are attempting to summon and channel what might be called the 'university after the university'. Today, the university is the site of the harnessing and leveraging of its denizens' virtuosity toward the reproduction of the hegemonic institution and the form of neoliberal capitalism it has been made to serve. It is an institution adept at displacing or externalizing its own crises onto its inhabitants (students, teachers, staff) in the form of student debt, chronic over-work, and precariousness. In the world we might seek to build beyond the crisis and beyond capitalist reproduction, the university will have to become something radically different. How might the university become a fulcrum for the production and facilitation of new forms of social reproduction? How might academics grasp this potential and put it to work in the present? How can we envision our work as academic-activists, not as saviours or as bystanders of social movements, but as partners, accomplices, and co-conspirators? More importantly, how can we, today, take up the mantle of the scholars we might yet become in the world we might build together? That is, how can we, borrowing the language of prefigurative politics, imagine prefigurative methodologies? These would be methodologies borrowed from what seems like an impossible future; one where our role might be facilitating healthy, honest, and robust forms of social reproduction. 


\section{References}

Althusser, L. (2014). On the reproduction of capitalism: Ideology and ideological state apparatuses. London \& New York: Verso.

Appadurai, A. (1996). Modernity at large: Cultural dimensions of globalization. Minneapolis, MN: University of Minnesota Press.

Berardi, F. B. (2012). The uprising: On poetry and finance. Los Angeles: Semiotext(e).

Bourdieu, P. (1993). The field of cultural production: Essays on art and literature. (R. Johnson, Ed.). New York: Columbia University Press.

Butler, J. (2006). Gender trouble: Feminism and the subversion of identity. New York: Routledge.

Caffentzis, G. (2013). In letters of blood and fire: Work, machines, and the crisis of capitalism. Oakland, CA: PM Press.

Castoriadis, C. (1997). The Castoriadis reader. (D. A. Curtis, Trans.). Oxford \& Malden, MA: Blackwell.

Cleaver, H. (2000). Reading Capital politically. Edinburgh \& Leeds: AK Press.

Colectivo Situaciones. (2011). 19 \& 20: Notes for a new social protagonism. Wivenhoe, UK: Minor Compositions.

Conway, J. (2004). Identity, place, knowledge: Social movements contesting globalization. Halifax, NS: Fernwood.

Dalla Costa, M., \& James, S. (1975). The power of women and the subversion of the community (3rd ed.). Bristol: Falling Wall Press Ltd.

Davis, A. Y. (2005). Abolition democracy: Beyond empire, prisons, and torture. New York: Seven Stories Press.

Day, R. (2005). Gramsci is dead: Anarchist currents in the newest social movements. Toronto: Between the Lines.

De Angelis, M. (2007). The beginning of history: Value struggles and global capital. London: Pluto.

Dixon, C. (2014). Another politics: Talking across today's transformative movements. Berkeley, CA: University of California Press.

Dyer-Witheford, N. (1999). Cyber-Marx: Cycles and circuits of struggle in high-technology capitalism. Urbana, IL: University of Illinois Press.

Edu-factory Collective. (2009). Toward a global autonomous university. New York: Autonomedia.

Eisenstein, Z. R. (2004). Against empire: Feminisms, racism, and the West. London: Zed Books.

Fanon, F. (1982). Black skin, white masks. New York: Grove Press.

Federici, S. (2003). Caliban and the witch: Women, the body and primitive accumulation. New York: Autonomedia.

Federici, S. (2012). Revolution at point zero: Housework, reproduction, and feminist struggle. Oakland, CA: PM Press.

Frampton, C., Kinsman, G., Thompson, A. K., \& Tilleczek, K. (Eds.). (2006). Sociology for changing the world: Social movements/social research. Black Point, N.S: Fernwood.

Gilroy, P. (1993). The black Atlantic: Modernity and double consciousness. Cambridge, MA: Harvard University Press.

Haiven, M., \& Khasnabish, A. (2011). What is the radical imagination: A special issue. Affinities, 4(2), i-xxxvii.

Haiven, M., \& Khasnabish, A. (2013). Between success and failure: Dwelling with social movements in the hiatus. Interface: A Journal for and about Social Movements, 5(2), 472498

Haiven, M., \& Khasnabish, A. (2014). Radical imagination: Social movement research in the age of austerity. Halifax, NS \& London: ZED Books \&Fernwood.

Hall, S. (1986). The problem of ideology-Marxism without guarantees. Journal of Communication Inquiry, 10(2), 28-44.

Hall, S. (1993). What is this "Black" in Black popular culture? Social Justice, 20(1-2), 104-114.

Hall, S. (Ed.). (1997). Representation: Cultural representations and signifying practices. London \& Thousand Oaks, CA: Sage.

Studies in Social Justice, Volume 9, Issue 1, 18-33, 2015 
Haraway, D. J. (1991). Simians, cyborgs, and women: The reinvention of nature. New York: Routledge.

Hardt, M., \& Negri, A. (2000). Empire. Cambridge, MA: Harvard University Press.

Harney, S., \& Moten, F. (2013). The undercommons: Fugitive planning \& black study. New York: Minor Compositions.

Harvey, D. (2006). The limits to capital. London \& New York: Verso.

Haworth, R. H. (Ed.). (2012). Anarchist pedagogies: Collective actions, theories, and critical reflections on education. Oakland, CA: PM Press.

Hoggart, R. (1998). The uses of literacy. New Brunswick, NJ: Transaction Publishers.

Holloway, J. (2002). Change the world without taking power: The meaning of revolution today. London: Pluto Press.

Holloway, J. (2010). Crack capitalism. London: Pluto.

hooks, b. (2000). Feminist theory: From margin to center (2nd ed.). Cambridge, MA: South End Press.

Juris, J. (2008). Networking futures: The movements against corporate globalization. Durham: Duke University Press.

Juris, J. S., \& Khasnabish, A. (Eds.). (2013). Insurgent encounters: Transnational activism, ethnography, and the political. Durham, NC \& London: Duke University Press.

Khasnabish, A. (2008). Zapatismo beyond borders: New imaginations of political possibility. Toronto: University of Toronto Press.

Khasnabish, A., \& Haiven, M. (2012). Convoking the radical imagination: Social movement research, dialogic methodologies, and scholarly vocations. Cultural Studies Critical Methodologies, 12(5), 408-421.

Kinsman, G. W., \& Gentile, P. (2010). The Canadian war on queers: National security as sexual regulation. Vancouver: UBC Press.

Luxemburg, R. (2003). The accumulation of capital. London \& New York: Routledge.

Maeckelbergh, M. (2009). The will of the many. London: Pluto Press.

Marx, K. (1981). Capital: A critique of political economy. (B. Fowkes, Trans.). London \& New York: Penguin.

Mies, M. (1986). Patriarchy and accumulation on a world scale: Women in the international division of labour. London: Zed Books.

Mills, C. W. (1997). The racial contract. Ithaca, NY: Cornell University Press.

Mohanty, C. T. (2003). Feminism without borders: Decolonizing theory, practicing solidarity. Durham, NC: Duke University Press.

Moten, F., \& Harney, S. (2013). The Undercommons: Fugitive planning \& black study. Wivenhoe, UK \& New York: Minor Compositions.

Polletta, F. (2002). Freedom is an endless meeting : Democracy in American social movements. Chicago: University of Chicago Press.

Ross, A. (2009). Nice work if you can get it: Life and labor in precarious times. New York: NYU Press.

Shiva, V. (1988). Staying alive: Women, ecology, and development. London: Zed Books.

Shukaitis, S., Graeber, D., \& Biddle, E. (Eds.). (2007). Constituent imagination. Oakland, CA: AK Press.

Sitrin, M. (2012). Everyday revolutions: Horizontalism and autonomy in Argentina. London \& New York: Zed Books.

Sitrin, M., \& Azzellini, D. (2014). They can't represent us!: Reinventing democracy from Greece to Occupy. London \& Brooklyn, NY: Verso.

Taylor, C. (2004). Modern social imaginaries. Durham, NC: Duke University Press.

Turbulence Collective. (2010). What would it mean to win?. Oakland, CA: PM Press.

Walia, H. (2013). Undoing border imperialism. Oakland, CA: AK Press.

Wood, L. J. (2012). Direct action, deliberation, and diffusion: Collective action after the WTO protests in Seattle. Cambridge: Cambridge University Press.

Wood, L.J. (2014). Crisis and control: The militarization of protest policing. London: Pluto. 